and central Europe seem to have been more or less connected during and since the Cambrian period, with intermigrations of life-forms. This connection, with probable interruptions, appears to have continued down to the early centuries of the Quarternary. Also, from what little we know of the extinct animals and of the present relations of the plants and animals of the continents south of latitude $20^{\circ}$ north, several observers have been led to suppose that these continents were more or less intimately united, and that possibly there were land connections with a former Antaretic continent. From maps, though naturally very hypothetical, published by de Lapparent and Koken, showing the probable distribution of land during the Middle Devonian, South America, Africa, southern Asia and Australia were possibly connected. Towards the end of the Carboniferous period there was probably a more or less continuous extent of land over what is now South America, Africa and Australia. This land connection between what are now separate continents appears to have persisted through the early Mesozoic age (Trias and Jura), though towards the end of the Jurassic Australia became widely separated by the Indian Ocean from Africa, while South America and Africa remained united. Our studies on the distribution of Neogæic and African (Ethiopian) Ceratocampidæ and two related families point to a connection in Cretaceous or early Tertiary times between Brazil and western Africa, thus bearing out the views of Ihering, Gill, Ortmann and others. The former connection of these Antarctogæic continents (whatever may be said of their possible connection with Antarctica) is borne out by the well-known facts in the distribution of certain terrestrial worms, land and fresh-water mollusks, insects, fresh-water fish, Dipnoi, Peripatus, am- phibians, reptiles, birds and mammals. Our results also suggest that Africa south of the Sahara should properly be regarded as a zoological realm (for which the word Afrogæa is proposed), and not a dependence or region of Arctogæa.

$$
\begin{aligned}
& \text { C. Judson HerRICK, } \\
& \text { Secretary. }
\end{aligned}
$$

\section{AMERICAN SOCIETY OF ZOOLOGISTS, CENTRAL BRANCH.}

THe first annual meeting under the present organization was held at St. Louis, December 29 and 30 . The following officers were elected for the ensuing year:

President-Professor C. H. Eigenmann.

Vice-President-Dr. S. J. Holmes.

Secretary and Treasurer-Professor F. R. Lillie. Additional Members of the Executive Committee -One year, Professor G. A. Lefevre; two years, Professor T. G. Lee; three years, Professor Herbert Osborn.

The titles and abstracts of the papers presented appear together with those presented by Section F of the American Association for the Advancement of Science, in Professor Herrick's report printed above.

\section{Frank Smith,} Secretary.

\section{SCIENTIFIC BOOKS.}

Evolution and Adaptation. By Thomas Hunt Morgan. The Macmillan Company. 1903. Pp. 470.

The modern evolutionist is obliged to confess, and somewhat painfully, that the processes connected with 'Darwinism' continue to receive different and conflicting explanations -this, too, in the face of a mass of documents which an ever-increasing number of investigators have been bringing together during the past decades. In token of this lack of concord in interpretation witness two volumes, not mere tracts, which have lately appeared. In the first of these, Plate, ${ }^{*}$ following Darwinian

* Ueber die Bedeutung des Darwin'schen Selectionsprincips und Probleme der Artbildung,' Zweite, vermehrte Auflage, 1903, Engelmann, pp. 247. 